\title{
Studies on the Phospholipid Metabolism in Choline-Deficient Guinea Pigs
}

\author{
I. Increased Activity of Lecithin Synthesis in Liver Slices ${ }^{1}$
}

\author{
Shigeru Suzuki, ${ }^{2}$ Masanao Kobayashi \\ AND YAHITO KOTAKE ${ }^{3}$ \\ Second Department of Biochemistry, Schooll of Medicine, \\ Nagoya University, Nagoya (Post No. 466)
}

(Received October 15, 1969)

1. Lecithin syntheses from four radioactive precursors in liver slices were compared between the choline-deficient and the choline-supplemented (control) guinea pigs.

2. In the choline-deficient group, more ${ }^{32} \mathrm{PO}_{4}$ was incorporated into lecithin than into phosphatidylethanolamine, whereas this relationship was reversed in the control group.

3. Incorporation of choline $-{ }^{14} \mathrm{CH}_{3}$ into lecithin in the choline-deficient group was twice as great as that in the control.

4. No difference was observed between the two groups in the incorporation of ethanolamine $-{ }^{14} \mathrm{C}$ into phosphatidylethanolamine. However, a larger part of the incorporated radioactivity was found in lecithin in the choline-deficient group than in the control.

5. Incorporation of labeled methyl group from L-methionine- $\mathrm{C}^{3} \mathrm{H}_{3}$ was also doubled in the choline-deficient group as compared with the control.

6. As the activity of methionine activating enzyme was almost at the same level in the two groups, the higher activity of phosphatidylmethyltransferase system was expected to be responsible for the higher phospholipid methylating activity in the choline-deficient group.

7. Incorporation of labeled methyl group into phospholipids was augmented nearly twice by preincubating the slices with $\mathrm{N}$-methylethanolamine or $\mathrm{N}, \mathrm{N}$ dimethylethanolamine prior to the addition of L-methionine- $\mathrm{C}^{3} \mathrm{H}_{3}$.

Guinea pigs fed a diet lacking choline show some features different from cholinedeficient rats; young guinea pigs maintained on a choline-deficient diet show marked retardation in growth and many of them die in a few weeks (1-3). At autopsy, no marked deposition of fat was observed at the end of the fourth week in the livers of the animals fed on a choline-deficient diet (4-6). The reason why young guinea pigs cannot grow without a supplement of choline in a semisynthetic diet has been explained that lecithin cannot be synthesized via the methylation of phosphatidylethanolamine in this animal $(6,7)$.

\footnotetext{
${ }^{1}$ Following abbreviations are used: MME, $N$-methylethanolamine; DME, $N, N$-dimethylethanolamine; TLC, thin layer chromatography.

2 Present address: Department of Experimental Radiology, Research Institute of Aichi Cancer Center, Nagoya.

3 鈴木 茂, 小林正直, 古武弥人.
} 
On the other hand, the failure to produce fatty livers in guinea pigs, different from the observation in rats, by dietary choline deficiency was reported (4-6), and ascribed by Handler to the low level of choline oxidase and to the slow turnover of choline in guinea pig liver (4). In our previous observation, one-third of the young guinea pigs maintained on a choline-deficient diet were still alive at the end of the fourth week $(2,3)$, and some of them survived after 6-8 weeks, occasionally showing a rather better growth. Therefore, it was expected that lecithin might be synthesized, partially at least, through the methylation pathway in guinea pig liver, and this alternative pathway might be of significance in a choline-deficient state.

Present report describes some experiments designed to evaluate the synthesis of lecithin from radioactive precursors in the liver slices of guinea pigs fed the choline-deficient and the choline-supplemented diet. Special attention will be paid to the methylation pathway in the latter part of this report.

\section{EXPERIMENTAL}

\section{Animals}

Male and female guinea pigs, ranging in weight from 140 to $190 \mathrm{~g}$, were fed ad libitum for four weeks a semisynthetic diet essentially based on Reid (1) and reported in detail previously (3), which contained 30 $\%$ vitamin-free casein, $7.3 \%$ rape oil, $53.1 \%$ carbohydrates, $9 \%$ salts and sufficient amount of the known vitamins except choline (in the cholinedeficient group). In the control group $0.2 \%$ choline chloride was supplemented to the above diet.

\section{Chemicals}

Phosphate- ${ }^{32} \mathrm{P}$ (27.6 mCi / mmole), choline ${ }^{14} \mathrm{CH}_{3}$ chloride $(32 \mathrm{mCi} / \mathrm{mmole})$, L-methionine- $\mathrm{C}^{3} \mathrm{H}_{3}(143 \mathrm{mCi} /$ mmole), L-methionine $-{ }^{14} \mathrm{CH}_{3} \quad(53.7 \mathrm{mCi} / \mathrm{mmole})$ and ethan-1-ol-2-amine- $2 .{ }^{14} \mathrm{C}$ hydrochloride $44.86 \mathrm{mCi}$ / mmole) were all supplied from the Radio Chemical Centre, Amersham, England. ATP and GSH were the products of Sigma Chemical Co.. Dotite DPO (2,5-diphenyloxazole) and Dotite POPOP (1,4-bis-[2-(5phenyloxazolyl)]-benzene) were purchased from Wako Pure Chemical Industries, Osaka. Ethanolamine hydrochloride, $N$-methylethanolamine (MME) and $N, N$ dimethylethanolamine (DME) were obtained from Tokyo Kasei Kogyo Co., Tokyo. Avicel (microcrystal- line cellulose for TLC) and most of the other reagents used were supplied from Katayama Chemicals Co., Osaka, and were of analytical grade.

\section{Incorporation of Radioactive Precursors} into Phospholipids of Liver Slices

At the end of the fourth week, the animals were killed by decapitation, livers were quickly excized, placed in icecold $0.9 \% \mathrm{NaCl}$, weighed and cut into slices weighing $50-80 \mathrm{mg}$ using a slicer. Two slices were put into $2 \mathrm{ml}$ of Krebs-Ringer bicarbonate buffer (pH 7.4) containing various additions in a small test tube $(1.5 \times 10 \mathrm{~cm})$ equipped with a rubber plug. The tubes were gassed with a mixture of 95 $\% \mathrm{O}_{2}$ and $5 \% \mathrm{CO}_{2}$ and incubated at $37^{\circ}$ in a shaking incubator with gassing every $30 \mathrm{~min}$. The incubation was always done in duplicate. At the end of the incubation period the slices were taken up, quickly washed with ice-cold water, blotted, weighed, put into $2 \mathrm{ml}$ of chloroform-methanol $(2: 1)$ and homogenized with a small hand-driven glass homogenizer. After shaking at $37^{\circ}$ for $30 \mathrm{~min}$, the homogenate was passed through a glass wool filter to remove the insoluble matter. The filtrate was wahed with $0.5 \mathrm{ml}$ of $0.04 \% \mathrm{MgCl}_{2}$ solution according to Folch et al. (8), and evaporated in vacuo to dryness under a stream of nitrogen. The residue was dissolved in $2 \mathrm{ml}$ of chloroform-methanol $(2: 1)$; a 0.2 $\mathrm{ml}$ aliquot was used for the assay of total radioactivity incorporated into phospholipids, and two $0.1 \mathrm{ml}$ aliquots for determination of total phospholipid-phosphorus. The rest of the extract was used for TLC.

4. Fractionation of Lipids with Thin Layer Chromatography

Thin layer chromatography of crude lipid extract was carried out on Kieselgel G (Merck) plates of 1 $\mathrm{mm}$ thickness. The plates were developed with chloroform-methanol-water $(78: 25: 4)$ and the bands of the separated lipids were visualized in iodine vapor (Fig. 1). After the color of iodine had disappeared, the marked bands of phosphatidylethanolamine (D) and phosphatidylcholine (C), previously identified by ninhydrin and Dragendorff's reagent, respectively, were scraped into counting vials for assay of radioactivity.

Phosphorus content of lecithin and phosphatidylethanolamine was also analyzed on the scraped bands. when an appropriate portion of the plate was used as a blank.

\section{Fractionation of Phospholipid Bases}

Phospholipids extracted from the incubated slices were hydrolyzed for 6 hours in $3 \mathrm{~N} \mathrm{HCl}$ in methanol, containing $1 \mu$ mole of $\mathrm{MME}$ and $1 \mu$ mole of DME as carriers; the hydrolyzate was washed with ether to 


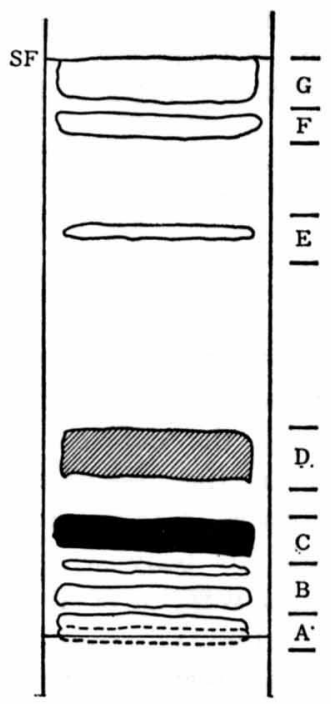

FIG. 1 Thin layer chromatography of liver lipids on silisic acid plate

The developing solvent was chloroform-methanolwater $(78: 25: 4)$. See the text for detail.

remove fatty acids and evaporated in vacuo to dryness. The residue was extracted with a small volume of water and phospholipid bases contained were chromatographed on Avicel plates in thickness of 0.25 $\mathrm{mm}$, which were previously splayed with $1 \mathrm{M} \mathrm{KCl}$ and dried at room temperature in order to avoid tailing. The developing solvent consisted of $50 \mathrm{~g}$ phenol, $50 \mathrm{ml} n$-butanol, $3 \mathrm{ml}$ of $80 \%$ formic acid and $10 \mathrm{ml}$ of water; the mixture was saturated with solid $\mathrm{KCl}$ (9). The above TLC system gave a rapid and good separation of choline (CHOL.), DME, MME, ethanolamine (EA) and serine (Ser.) (Fig. 2). The bands of the separated bases were detected in iodine vapor and identified with ninhydrin, Dragendorff's reagent and the $R f$ of the authentic substances. The bands of choline, DME and MME were scraped into counting vials for radioactivity assay.

\section{Assay for Radioactivity}

All radioactivity measurements were carried out in a liquid scintillation spectrophotometer (Model GSL-163, Kobe Kogyo, Kobe) using a scintillator solution containing $0.4 \%$ DPO and $0.01 \%$ POPOP in toluene $(\mathrm{w} / \mathrm{v})$. The sample put into a counting vial was mixed with $1 \mathrm{ml}$ of methanol (for lipids) or $2 \mathrm{ml}$ of ethyleneglycol monomethylether (for watersoluble substances), followed by the addition of $10 \mathrm{ml}$ of the scintillator solution. To avoid the effect of different and relatively high quenching, especially in the case of samples from TLC plates, cpm values of

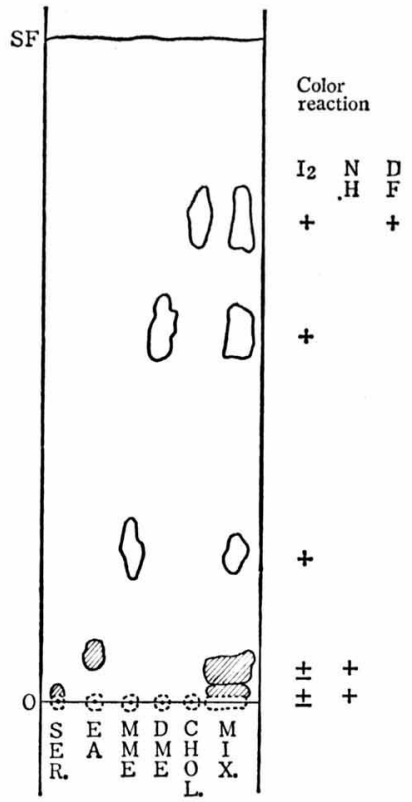

FIG. 2 Thin layer chromatography of authentic phospholipid bases on avicel plate

Each $1 \mu$ mole of the authentic material was spotted on the plate and developed with phenol-n-butanolformic acid-water. Ser., serine; EA, ethanolamine hydrochloride; CHOL., choline chloride; Mix., mixture of all bases. $\mathrm{I}_{2}$, iodine vapor; $\mathrm{NH}$, ninhydrin; $\mathrm{DF}$, Dragendorff's reagent. MME and DME were neutralized with $\mathrm{HCl}$ before use. + , positive; \pm , slightly positive.

the radioactive products were computed into disintegration per minute $(\mathrm{dpm})$ using the channel ratio method, or further into $\mathrm{m} \mu$ moles.

\section{Determination of Phosphorus and} Protein

Phospholipid phosphorus was determined as follows; aliquots of lipid extract were wet-ashed at 150$160^{\circ}$ for 1 hour with $0.8 \mathrm{ml}$ of $70 \%$ perchloric acid saturated with ammonium molybdate in test tubes $(1.5 \times 15 \mathrm{~cm})$. After addition of $4 \mathrm{ml}$ water, each tube was heated in boiling water for $10 \mathrm{~min}$ and cooled, followed by the addition of $0.6 \mathrm{ml}$ of $2.5 \%$ ammonium molybdate and $0.6 \mathrm{ml}$ of $10 \%$ solution of ascorbic acid. Then the tubes were incubated at $37^{\circ}$ for 2 hours, and the absorbance was measured at $820 \mathrm{~m} \mu$. Protein was determined by biuret method (10).

8. Assay for Methionine Activating Enzyme and ATPase in Liver Supernatant

Liver was homogenized in 3 volumes of $0.01 \mathrm{~N}$ acetic acid and centrifuged at $60,000 \times g$ for $40 \mathrm{~min}$. 
The activity of methionine activating enzyme ( $L$ methionine adenosyltransferase, EC 2.4.2.13) in the supernatant was assayed by the method of Cantoni and Durell (11), modified to a smaller scale. The supernatant $(0.2 \mathrm{ml})$ was incubated at $37^{\circ}$ for $30 \mathrm{~min}$ with $20 \mathrm{mM}$ ATP, $20 \mathrm{mM}$ L-methionine, $8 \mathrm{mM} \mathrm{GSH}$, $250 \mathrm{mM} \mathrm{MgCl}$ and $100 \mathrm{~mm}$ Tris- $\mathrm{HCl}$ buffer (pH 7.6) in a total volume of $0.5 \mathrm{ml}$. The incubation was done in duplicate, and a control incubation was run with a reaction medium of the same composition except that L-methionine was omitted. The reaction was stopped by adding $0.2 \mathrm{ml}$ of $6 \%$ perchloric acid, followed by the addition of $4 \mathrm{ml}$ water and centrifugation. The supernatant was then transferred into a $15 \mathrm{ml}$ graduated test tube containing $5 \mathrm{ml}$ of $15 \mathrm{mM}$ Tris- $\mathrm{HCl}$ buffer ( $\mathrm{pH} 7.4$ ) and $\mathrm{pH}$ was adjusted to 7.4 by adding $1 \mathrm{~N} \mathrm{NaOH}$ with one drop of $0.04 \%$ bromothymol blue as an indicator. After the adjustment of the volume to $10 \mathrm{ml}$, the solution was passed through a small column $(0.5 \times 3 \mathrm{~cm})$ of Dowex $1 \times 8$ (200-400 mesh, $\mathrm{Cl}^{-}$form), and the absorbance of the effluent was measured at $260 \mathrm{~m} \mu$. The net formation of $S$-adenosylmethionine was calculated, assuming the molar absorbance to be 16,000 .

ATPase activity of the supernatant was measured simultaneously, in order to account for the possible difference in methionine activating enzyme activity between choline-deficient and choline-supplemented group. The incubation conditions were the same as described for the assay of methionine activating enzyme, except that L-methionine was omitted. Liberated inorganic phosphate was determined by the method of Allen (12).

\section{REsults}

1. Growth, Liver Weight and Liver Phospholipids

Guinea pigs maintained on a cholinedeficient diet showed a marked growth disturbance. Although the deficient animals grew up slightly during the first week, virtually no growth was observed thereafter. The ratio of liver weight to body weight in cholinedeficient animals was lower than that in the control ones (Table 1).

Content of total phospholipid, phosphatidylcholine and phosphatidylethanolamine of the livers in both groups were compared in Table 2. Liver lipids from four animals of each group were pooled and phospholipid-P was analyzed. No difference was observed in the amount of phosphatidylethanolamine, whereas a slight decrease of phosphatidylcholine was noticed in the choline-deficient group.

TABLE 1

Effect of choline-deficiency on growth and liver weight

\begin{tabular}{|c|c|c|c|c|c|c|c|}
\hline \multirow{2}{*}{$\begin{array}{l}\text { Supplement } \\
\text { in diet }\end{array}$} & \multirow{2}{*}{ Sex } & \multirow{2}{*}{$\begin{array}{l}\text { No. of } \\
\text { animals }\end{array}$} & \multicolumn{2}{|c|}{ Body weight } & \multirow{2}{*}{$\frac{\mathrm{B}}{\mathrm{A}}$} & \multirow{2}{*}{$\begin{array}{l}\text { No. of } \\
\text { animals }\end{array}$} & \multirow{2}{*}{$\begin{array}{l}\text { Liver } \\
\text { weight }\end{array}$} \\
\hline & & & Initial (A) & 4 weeks (B) & & & \\
\hline \multirow{3}{*}{ Choline $(t)$} & & & $g$ & $g$ & & \multicolumn{2}{|c|}{$\mathrm{g} / 100 \mathrm{~g}$ body weigh } \\
\hline & Male & 13 & $173 \pm 12$ & $302 \pm 47$ & $1.74 \pm 0.20$ & 16 & $4.4 \pm 0.6$ \\
\hline & Female & 10 & $167 \pm 13$ & $295 \pm 34$ & $1.77 \pm 0.24$ & 12 & $4.6 \pm 0.6$ \\
\hline \multirow{2}{*}{ Choline $(-)$} & Male & 14 & $188 \pm 20$ & $196 \pm 18$ & $1.05 \pm 0.08^{a}$ & 12 & $3.7 \pm 0.5^{a}$ \\
\hline & Female & 8 & $178 \pm 14$ & $191 \pm 15$ & $1.09 \pm 0.03^{a}$ & 12 & $3.6 \pm 0.5^{a}$ \\
\hline
\end{tabular}

a $p<0.005$ (against choline-supplemented group)

TABLE 2

Content of total phospholipids, phosphatidylcholine and phosphatidylethanolamine in livers of choline-deficient and choline-supplemented guinea pigs

\begin{tabular}{|c|c|c|c|c|c|c|c|}
\hline \multirow[t]{2}{*}{$\begin{array}{l}\text { Supplement } \\
\text { in diet }\end{array}$} & \multirow[t]{2}{*}{ Sex } & \multirow{2}{*}{$\begin{array}{c}\begin{array}{c}\text { Total } \\
\text { phospholipids }\end{array} \\
\text { rmole/g liver }\end{array}$} & \multicolumn{2}{|c|}{$\begin{array}{l}\text { Phosphatidyl- } \\
\text { choline (A) }\end{array}$} & \multicolumn{2}{|c|}{$\begin{array}{l}\text { Phosphatidyl- } \\
\text { ethanolamine (B) }\end{array}$} & \multirow[t]{2}{*}{$\frac{\mathrm{A}}{\mathrm{B}}$} \\
\hline & & & percent & umole/g liver & percent & umole/g liver & \\
\hline \multirow{2}{*}{ Choline $(+)$} & Male & 34.0 & 48.3 & 16.5 & 26.8 & 9.06 & 1.82 \\
\hline & Female & 32.0 & 45.2 & 14.5 & 28.8 & 9.24 & 1.58 \\
\hline \multirow{2}{*}{ Choline $(-)$} & Male & 31.0 & 43.2 & 13.3 & 30.2 & 9.31 & 1.43 \\
\hline & Female & 30.3 & 41.5 & 12.5 & 30.3 & 9.20 & 1.37 \\
\hline
\end{tabular}




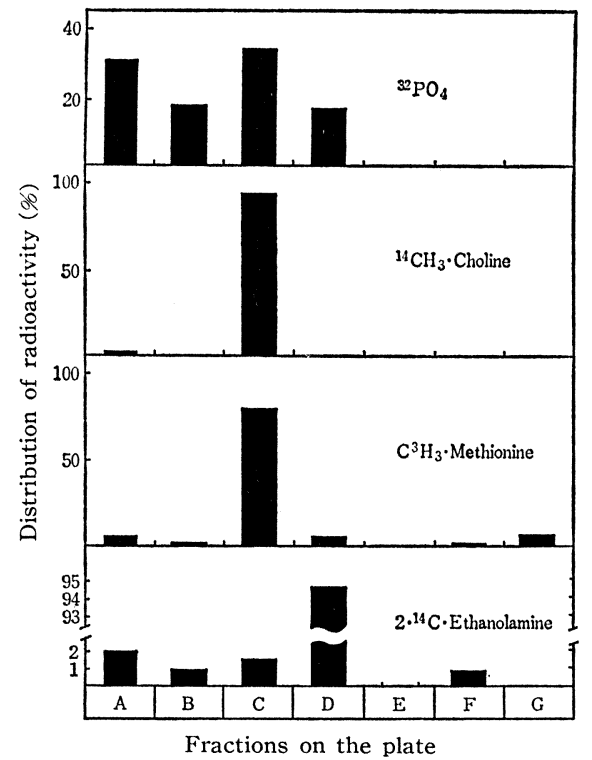

FIG. 3 Distribution of radioactive precursors incorporated into phospholipids of liver slices

Lipids extracted from the liver slices incubated with one of the four radioactive precursors were separated by TLC on silicic acid plates.

\section{Incorporation of Radioactive Pre-} cursors into Phospholipids of Liver Slices

Fig. 3 shows the distribution of radioactive precursors incorporated into phospholipids of liver slices. Liver slices were incubated with one of the four radioactive precursors of phospholipids in the same manner as in Table 3-6. Lipids were extracted and separated by TLC on Kieselgel $G$ plates. The bands named A-G (Fig. 1) were scraped into counting vials, and counted. The radioactivity was expressed in per cent of the sum of dpm contained in each band. The recovery from the radioactivity applied on the plates was 75-90\%.

The radioactivity from choline $-{ }^{14} \mathrm{CH}_{3}$ and L-methionine- $\mathrm{C}^{3} \mathrm{H}_{3}$ were found almost exclusively in the $\mathrm{C}$-fraction (lecithin). In the case of ethanolamine ${ }^{14} \mathrm{C}$ more than $90 \%$ of the isotope was incorporated into the D-fraction (phosphatidylethanolamine), but a small percentage was detected in the A-, B- and C-fractions.

${ }^{32} \mathrm{PO}_{4} \longrightarrow$ Table 3 shows the incorporation of ${ }^{32} \mathrm{PO}_{4}$ into phospholipids of liver slices. Liver slices were incubated at $37^{\circ}$ for $90 \mathrm{~min}$ in $2 \mathrm{ml}$ Krebs-Ringer bicarbonate buffer ( $\mathrm{pH}$ 7.4) containing approximately $10 \mu \mathrm{Ci}$ of ${ }^{32} \mathrm{PO}_{4}$, $0.2 \mu$ moles of ethanolamine hydrochloride and $0.2 \mu$ moles of $\mathrm{L}$-methionine. The concentration of $\mathrm{PO}_{4}$ in the buffer was $1.2 \mathrm{~mm}$. Phospholipids were extracted, separated and counted. Incorporation of radioactivity into the phosphatidylcholine fraction relative to that into the phosphatidylethanolamine fraction was higher in the choline-deficient group than in the control group.

Choline ${ }^{-14} \mathrm{CH}_{3}$ - Liver slices were incubated for $90 \mathrm{~min}$ at $37^{\circ}$ in $2 \mathrm{ml}$ KrebsRinger bicarbonate buffer ( $\mathrm{pH}$ 7.4) containing choline $-{ }^{14} \mathrm{CH}_{3} \quad(1 \mu \mathrm{Ci}, 0.22 \mu$ moles $)$. Phospholipids were extracted and counted (Table 4). In female animals higher radioactivity was incorporated in the choline-deficient group than in the control one. In the males the incorporation showed relatively wide scattering, but when the data were treated statistically disregarding the sex, the difference be-

TABLE 3

Incorporation of ${ }^{32} \mathrm{PO}_{4}$ into phospholipids of liver slices

\begin{tabular}{|c|c|c|c|c|c|c|}
\hline \multirow{2}{*}{$\begin{array}{l}\text { Supplement } \\
\text { in diet }\end{array}$} & \multirow{2}{*}{ Sex } & \multirow{2}{*}{$\begin{array}{l}\text { No. of } \\
\text { animals }\end{array}$} & \multicolumn{3}{|c|}{ Incorporation of ${ }^{32} \mathrm{PO}_{4}$ into } & \multirow{2}{*}{$\frac{B}{A}$} \\
\hline & & & $\begin{array}{c}\text { Total } \\
\text { phospholipids }\end{array}$ & $\begin{array}{l}\text { Phosphatidyl- } \\
\text { ethanolamine (A) }\end{array}$ & $\begin{array}{l}\text { Phosphatidyl- } \\
\text { choline (B) }\end{array}$ & \\
\hline & \multicolumn{6}{|c|}{$c p m / \mu m o l e ~ l i p i d-P\left(\times 10^{4}\right)$} \\
\hline \multirow{2}{*}{ Choline $(+)$} & Male & 4 & $5.33 \pm 1.05$ & $1.06 \pm 0.31$ & $0.91 \pm 0.29$ & $0.89 \pm 0.23$ \\
\hline & Female & 4 & $5.48 \pm 0.71$ & $0.91 \pm 0.33$ & $0.75 \pm 0.24$ & $0.79 \pm 0.12$ \\
\hline \multirow{2}{*}{ Choline $(-)$} & Male & 4 & $5.41 \pm 1.04$ & $1.07 \pm 0.24$ & $1.41 \pm 0.49$ & $1.30 \pm 0.17^{b}$ \\
\hline & Female & 4 & $5.55 \pm 0.28$ & $1.09 \pm 0.22$ & $1.61 \pm 0.36^{a}$ & $1.39 \pm 0.31^{b}$ \\
\hline
\end{tabular}

a $p<0.005$ (against choline-supplemented group)

$b 0.01<p<0.025$ (against choline-supplemented group) 
TABLE 4

Incorporation of choline ${ }^{14} \mathrm{CH}_{3}$ into phospholipids of liver slices

\begin{tabular}{|c|c|c|c|}
\hline $\begin{array}{l}\text { Supplement } \\
\text { in diet }\end{array}$ & Sex & $\begin{array}{c}\text { No. of } \\
\text { animals }\end{array}$ & $\begin{array}{l}\text { Incorporation of } \\
\text { choline }{ }^{-14} \mathrm{CH}_{3}\end{array}$ \\
\hline & & & $\begin{array}{c}d p m / \mu m o l e \\
\text { lipid-P( }\left(\times 10^{4}\right)\end{array}$ \\
\hline Choline $(+)$ & $\begin{array}{l}\text { Male } \\
\text { Female }\end{array}$ & $\begin{array}{l}4 \\
5\end{array}$ & $\begin{array}{l}1.61 \pm 0.67 \\
1.51 \pm 0.35\end{array}$ \\
\hline Choline (--) & $\begin{array}{l}\text { Male } \\
\text { Female }\end{array}$ & $\begin{array}{l}4 \\
5\end{array}$ & $\begin{array}{l}2.29 \pm 0.90 \\
2.99 \pm 1.05^{a}\end{array}$ \\
\hline
\end{tabular}

$a 0.01<p<0.025$ (against choline-supplemented group)

TABLE 5

Incorporation of L-methionine- $\mathrm{C}^{3} \mathrm{H}_{3}$ into phospholipids of liver slices

\begin{tabular}{llcc}
\hline $\begin{array}{c}\text { Supplement } \\
\text { in diet }\end{array}$ & Sex & $\begin{array}{c}\text { No. of } \\
\text { animals }\end{array}$ & $\begin{array}{c}\text { Incorporation of } \\
\text { L-methionine- } \mathrm{C}^{3} \mathrm{H}_{3}\end{array}$ \\
\hline & & & $\begin{array}{c}\text { dpm } / \mu m \text { mole } \\
\text { lipid-P( }\left(\times 10^{4}\right)\end{array}$ \\
Choline (+) & Male & 4 & $3.67 \pm 1.27$ \\
& Female & 5 & $4.36 \pm 1.36$ \\
\hline Choline (-) & Male & 4 & $7.02 \pm 2.31^{a}$ \\
& Female & 5 & $10.08 \pm 1.00^{b}$ \\
\hline
\end{tabular}

a $0.025<p<0.05$ (against choline-supplemented group)

${ }^{b} p<0.005$ (against choline-supplemented group)

tween the two groups was significant $(p<0.01)$.

L-Methionine- $\mathrm{C}^{3} \mathrm{H}_{3}$ - Liver slices were incubated at $37^{\circ}$ for $90 \mathrm{~min}$ in $2 \mathrm{ml}$ KrebsRinger bicarbonate buffer ( $\mathrm{pH}$ 7.4) containing L-methionine- $\mathrm{C}^{3} \mathrm{H}_{3}(5 \mu \mathrm{Ci}, 0.24 \mu$ moles $)$ and 0.2 $\mu$ moles of ethanolamine hydrochloride. Phospholipids were extracted and counted (Table 5). The incorporation of labeled methyl group in the choline-deficient group was nearly twice as high as that in the control group. Most of the radioisotope incorporated into phospholipids was found in the lecithin fraction (Fig. 3), and it was interpreted that ethanolamine moiety of phosphatidylethanolamine was methylated to form lecithin. The small amount of radioactivity found in the phosphatidylethanolamine fraction (3-5\%) might be due to the partially methylated intermediates (phosphatidyl-MME and phosphatidylDME), which might have contaminated the phosphatidylethanolamine fraction in the present chromatographic system $(13,14)$.

Ethanolamine-2-14 $\mathrm{C}$ - Table 6 shows the incorporation of ethanolamine $-2{ }^{14} \mathrm{C}$ into phospholipids of liver slices. Liver slices were incubated at $37^{\circ}$ for $90 \mathrm{~min}$ in $2 \mathrm{ml}$ Krebs-Ringer bicarbonate buffer $(\mathrm{pH} 7.4)$ containing ethanolamine $-2-{ }^{14} \mathrm{C}$ hydrochloride (1 $\mu \mathrm{Ci}, 0.21 \mu$ moles) and $0.2 \mu$ moles of L-methionine. Phospholipids were extracted, separated and counted. Low radioactivity in phosphatidylcholine in comparison to that in phosphatidyl-ethanolamine seems to be due in part to the dilution of the radioisotope, prior to methylation, with the endogenous phosphatidylethanolamine, which is one of the most abundant phospholipids of the liver.

The relative amount of phosphatidylcholine and phosphatidylethanolamine freshly synthesized from each precursor, expressed as mumoles precursor incorporated $/ \mu$ mole lipid-P of the product phospholipid, was calculated from dpm value, and summarized in Fig. 4. Much easier incorporation of ethanolamine${ }^{14} \mathrm{C}$ into phosphatidylethanolamine than that of ${ }^{32} \mathrm{PO}_{4}$ seems to suggest that an "exchange

TABLE 6

Incorporation of ethanolamine-2.14C into phospholipids of liver slices

\begin{tabular}{|c|c|c|c|c|c|c|}
\hline \multirow{2}{*}{$\begin{array}{l}\text { Supplement } \\
\text { in diet }\end{array}$} & \multirow[b]{2}{*}{ Sex } & \multirow{2}{*}{$\begin{array}{l}\text { No. of } \\
\text { animals }\end{array}$} & \multicolumn{3}{|c|}{ Incorporation of ethnolamine $-2{ }^{-14} \mathrm{C}$ into } & \multirow{2}{*}{$\frac{\mathrm{B}}{\mathrm{A}}$} \\
\hline & & & $\begin{array}{c}\text { Total } \\
\text { phospholipids }\end{array}$ & $\begin{array}{l}\text { Phosphatidyl- } \\
\text { ethanolamine (A) }\end{array}$ & $\begin{array}{l}\text { Phosphatidyl- } \\
\text { choline (B) }\end{array}$ & \\
\hline & & & & $d p m / \mu m o l e ~ l i p i d-\mathrm{P}$ & & \\
\hline \multirow{3}{*}{ Choline $(+)$} & & & $\times 10^{4}$ & $\times 10^{4}$ & $\times 10^{2}$ & $\times 10^{-2}$ \\
\hline & Male & 4 & $5.73 \pm 2.06$ & $4.78 \pm 1.44$ & $3.98 \pm 1.73$ & $0.94 \pm 0.45$ \\
\hline & Female & 4 & $5.57 \pm 1.76$ & $4.14 \pm 0.81$ & $4.80 \pm 0.84$ & $1.20 \pm 0.08$ \\
\hline \multirow{2}{*}{ Choline $(-)$} & Male & 4 & $4.62 \pm 1.32$ & $3.88 \pm 1.30$ & $4.90 \pm 1.76$ & $1.65 \pm 0.15^{a}$ \\
\hline & Female & 4 & $5.88 \pm 1.29$ & $4.80 \pm 1.12$ & $6.76 \pm 1.88$ & $1.62 \pm 0.33^{b}$ \\
\hline
\end{tabular}

a $0.01<p<0.025$ (against choline-supplemented group)

$b 0.025<p<0.05$ (against choline-supplemented group) 


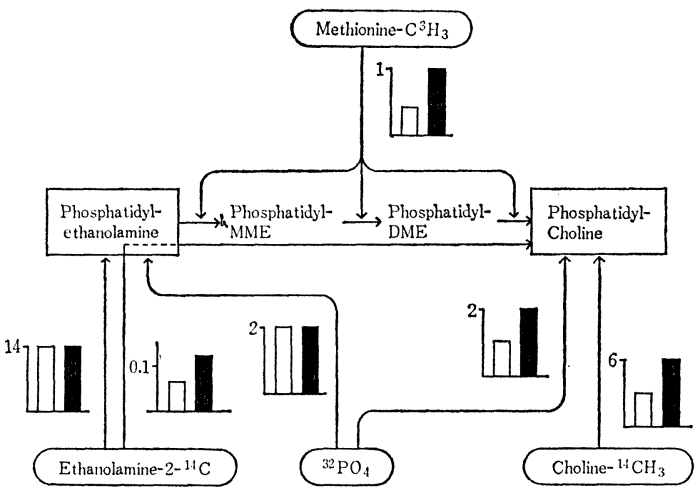

FIG. 4 A schematic representation of synthesis of lecithin from four labeled precursors in liver slices of choline-deficient and choline-supplemented guinea pigs

White columns, choline-supplemented group; black columns, choline-deficient group. The figures on the ordinate indicate $\mathrm{m} \mu$ moles precusor incorporated $/ \mu$ mole phosphorus of the product phospholipid.

reaction" at the base moiety of the intact molecule without the renewal of phosphate (15), rather than a de novo synthesis through Kennedy's pathway (16), plays a larger part in the present conditions. In liver slices of the choline-deficient guinea pigs, the ability to synthesize lecithin from any of the four precursors was approximately twice as high as that in the slices of the control animals, whereas the synthesis of phosphatidylethanolamine was not affected. The enhancement of lecithin synthesis through methylation is of special significance, since this pathway means a de novo synthesis of choline moiety and perhaps serves as an alternative route to supplement it in a choline-deficient state.

3. Methionine Activating Enzyme Activity in Liver Supernatant

Two possible factors were postulated that

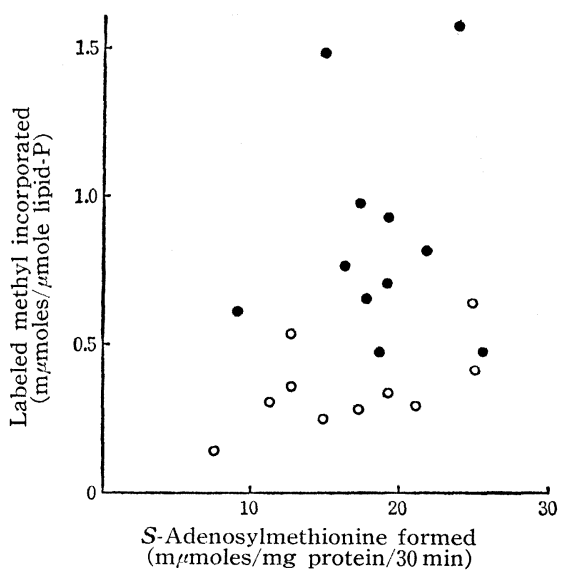

FIG. 5 Relationship between incorporation of labeled methyl group of L-methionine- $\mathrm{C}^{3} \mathrm{H}_{3}$ into phospolipids of liver slices and methionine activating enzyme activity in the liver Supernatant

Each spot represents the activity of methionine activating enzyme (abscissa) and of labeled methyl incorporation (ordinate), in the liver supernatant and the liver slices, respectively, obtained from the same animal. $\bigcirc$, choline-supplemented group ; $\bullet$, cholinedeficient group.

affect directly the methylation pathway: (a) the ability to synthesize $S$-adenosylmethionine, the direct methyl donor, and $(b)$ the activity of methyl transferring enzyme(s). The amount of phosphatidylethanolamine was considered not to affect the methylation, since in the liver it was supposed to be present enough to saturate the methyltransferase(s).

Table 7 shows the activity of the methionine activating enzyme and of ATPase in the liver supernatant. No significant difference in both activities was observed between the choline-deficient and the control group. Both methionine activating enzyme activity and incorporation of labeled methyl group of me-

TABLE 7

Activity of methionine activating enzyme and ATPase in liver supernatant

\begin{tabular}{clccc}
\hline \hline $\begin{array}{c}\text { Supplement } \\
\text { in diet }\end{array}$ & Sex & $\begin{array}{c}\text { No. of } \\
\text { animals }\end{array}$ & $\begin{array}{c}\text { Methionine activating } \\
\text { enzyme activity }\end{array}$ & ATPase activity \\
\hline & & & $\begin{array}{c}\text { mpmoles S-adenosylmethionine } \\
\text { formed/mg protein }\end{array}$ & $\begin{array}{c}\text { mpmoles Pi liberated/mg } \\
\text { protein }\end{array}$ \\
Choline (+) & Male & 5 & $17.4 \pm 5.1$ & $78 \pm 26$ \\
& Female & 7 & $19.5 \pm 3.9$ & $55 \pm 23$ \\
\hline \multirow{2}{*}{ Choline (-) } & Male & 6 & $15.8 \pm 3.6$ & $102 \pm 21$ \\
& Female & 8 & $20.2 \pm 4.1$ & $91 \pm 26^{a}$ \\
\hline
\end{tabular}

a $0.01<p<0.025$ (against choline-supplemented group) 
thionine- $\mathrm{C}^{3} \mathrm{H}_{3}$ showed considerably wide scattering data, and the possible correlation of individual values might be disregarded in the comparison of the means. Therefore, in Fig. 5 was shown the relationship between methionine activating enzyme activity and labeled methyl incorporation, in the liver supernatant and the liver slices, respectively, obtained from the same animals. No parallelism of the two activity was observed in either group. It is postulated that the activity of methionine activating enzyme is not responsible for the higher values of incorporation of labeled methyl group from methionine- $\mathrm{C}^{3} \mathrm{H}_{3}$ into phospholipids of liver slices in the choline-deficient group than in the control group.

4. Effect of Preincubation with $M M E$ or DME on the Incorporation of Labeled Methyl Group of $\mathrm{L}-$ Methionine- $\mathrm{C}^{3} \mathrm{H}_{3}$ into Phospholipids of Liver Slices

Phosphatidylethanolamine has been believed to be methylated stepwisely with sadenosylmethionine as the methyl donor in rat liver (17-19), it was suggested that the transfer of the second and the third methyl groups to the partially methylated intermediate phosphatides was considerably more rapid than that of the first methyl group to phosphatidylethanolamine. Labeled MME or DME were reported to be incorporated into phosphatides and then methylated to form lecithin in rat liver preparations $(18,20-23)$. On the other hand, there have been several nutritional studies showing that MME + methionine, MME + betain or DME serve as substitutes

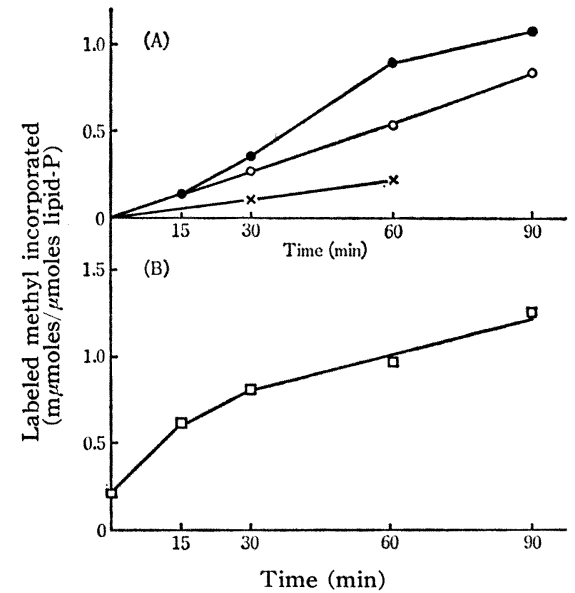

FIG. 6 Effect of preincubation with $M M E$ on the incorporation of methyl group of L-methionine${ }^{14} \mathrm{CH}_{3}$ into phospholipids of liver slices

$-\times-$, no preincubation; $-\mathbf{-}-$, the slices were transferred, after preincubation, into the medium containing L-methionine ${ }^{14} \mathrm{CH}_{3} ;-\mathrm{O}-$, L-methionine${ }^{14} \mathrm{CH}_{3}$ was added, after preincubation, into the same tube.

for choline in growth of young guinea pigs, but ethanolamine does not $(1,6)$. In consideration of these reports, experiments were performed to explore the effect of preincubation of the liver slices with those partially methylated ethanolamine derivatives on the incorporation of labeled methyl group of methionine into phospholipids, in order to elucidate whether the first methylation step was actually the rate limiting one in guinea pig liver, and whether any of the three methylation steps was specifically responsible

TABLE 8

Effect of preincubation with MME or DME on the incorporation of L-methionine-C ${ }^{3} \mathrm{H}_{3}$ into the phospholipids of liver slices

\begin{tabular}{|c|c|c|c|c|c|c|c|}
\hline \multirow{3}{*}{$\begin{array}{l}\text { Supplement } \\
\text { in diet }\end{array}$} & \multirow{3}{*}{ Sex } & \multirow{3}{*}{$\begin{array}{c}\text { No. of } \\
\text { animals }\end{array}$} & \multicolumn{3}{|c|}{ Preincubated base } & \multirow{3}{*}{$\frac{\mathrm{B}}{\mathrm{A}}$} & \multirow{3}{*}{$\frac{\mathrm{C}}{\mathrm{A}}$} \\
\hline & & & None (A) & MME (B) & DME (C) & & \\
\hline & & & \multicolumn{3}{|c|}{ Incorporation of $\mathrm{L}$-methionine- $\mathrm{C}^{3} \mathrm{H}_{3}$} & & \\
\hline \multicolumn{8}{|c|}{ mнmoles $/ \mu$ mole lipid $-P$} \\
\hline \multirow{2}{*}{ Choline $(+)$} & Male & 4 & $0.51 \pm 0.21$ & $0.94 \pm 0.54$ & $0.68 \pm 0.26$ & $1.76 \pm 0.36$ & $1.44 \pm 0.37$ \\
\hline & Female & 6 & $0.29 \pm 0.09$ & $0.63 \pm 0.24$ & $0.55 \pm 0.20$ & $2.15 \pm 0.40$ & $1.87 \pm 0.32$ \\
\hline \multirow{2}{*}{ Choline $(-)$} & Male & 4 & $0.76 \pm 0.15^{a}$ & $1.52 \pm 0.19^{a}$ & $1.22 \pm 0.16^{d}$ & $1.96 \pm 0.28$ & $1.64 \pm 0.27$ \\
\hline & Female & 5 & $0.64 \pm 0.17^{b}$ & $1.49 \pm 0.49^{c}$ & $1.25 \pm 0.58^{d}$ & $2.30 \pm 0.27$ & $1.88 \pm 0.63$ \\
\hline
\end{tabular}


for the higher methylation in the cholinedeficient group mentioned above.

Fig. 6 shows the time curves for the effect of preincubation with MME on the incorporation of labeled methyl group from methionine into phospholipids of liver slices. In Fig. $6(\mathrm{~A})$, liver slices were preincubated in $2 \mathrm{ml}$ Krebs-Ringer bicarbonate buffer $(\mathrm{pH}$ 7.4) containing $2 \mu$ moles of MME for $60 \mathrm{~min}$ at $37^{\circ}$, then the incorporation of labeled methyl was started either by an addition of L-methionine ${ }^{14} \mathrm{CH}_{3} \quad(0.3 \mu$ moles, $0.25 \mu \mathrm{Ci})$ in $1 \mathrm{ml}$ of the same buffer or by transferring the slices into another tube containing Lmethionine- ${ }^{14} \mathrm{CH}_{3}$ in $2 \mathrm{ml}$ buffer, and incubation was continued further for time indicated. These preincubated slices showed considerably higher incorporation of methyl group than the slices without preincubation, though the transferring method resulted in somewhat higher enhancement than the addition method. For convenience the latter method was used in the later experiment. In a preliminary experiment preincubation with ethanolamine did not show such an effect. In Fig. 6 (B) liver slices were preincubated with $1 \mathrm{mM}$ MME for time indicated, then transferred into a medium containing methionine- ${ }^{14} \mathrm{CH}_{3}$ and incubated for $60 \mathrm{~min}$ more. Preincubation for 30-60 min was found enough to give a maximal increment.

In a experiment shown in Table 8 , liver slices were preincubated at $37^{\circ}$ for $60 \mathrm{~min}$ in $2 \mathrm{ml}$ Krebs-Ringer bicarbonate buffer ( $\mathrm{pH} 7.4$ ) containing no base (None), $2 \mu$ moles of MME or $2 \mu$ moles of DME as indicated. L-Methio- nine- $\mathrm{C}^{3} \mathrm{H}_{3}(0.3 \mu$ moles, $1.5 \mu \mathrm{Ci})$ in $1 \mathrm{ml}$ of the same buffer was then added and incubation was continued for $60 \mathrm{~min}$ more. Phospholipids were extracted and counted. The MME- or DME-preincubated slices showed nearly twice as high incorporation as the non-preincubated ones, and in any case the choline-deficient group showed approximately twice as high values as the control. Assuming that the ratio $(\mathrm{B}) /(\mathrm{A})$ and $(\mathrm{C}) /(\mathrm{A})$ in Table 8 reflect the activity of the second and the third methylation, respectively, relative to the first, no significant difference was observed between the choline-deficient and the control group in this respect.

Distribution of the incorporated labeled methyl group among phospholipid bases were compared in Table 9. An aliquot of phospholipids extracted from some of the incubated liver slices of Table 8 was hydrolyzed with methanolic $2 \mathrm{~N} \mathrm{HCl}$. MME, DME and choline were separated from the hydrolyzate using Avicel TLC and the bands of these bases (Fig. 3) were scraped off and counted. The data are expressed in per cent assuming the sum of the radioactivity of these three bases as 100 , since other parts on the plates contained only little radioactivity.

From the total incorporation shown in Table 8 and the percentage in Table 9 , an approximate amount of methyl group incorporated into each of these three bases, expressed as $\mathrm{m} \mu$ moles methyl group incorporated $/ \mu$ mole lipid-P, was calculated and shown diagrammatically in Fig. 7.

It was only in the DME- fraction of the

TABLE 9

Distribution of labeled methyl group from L-methionine- $\mathrm{C}^{3} \mathrm{H}_{3}$ among phospholipid bases of liver slices

\begin{tabular}{|c|c|c|c|c|c|c|c|c|c|c|c|}
\hline \multirow{4}{*}{$\begin{array}{l}\text { Supplement } \\
\text { in diet }\end{array}$} & \multirow{4}{*}{ Sex } & \multirow{4}{*}{$\begin{array}{l}\text { No. of } \\
\text { animals }\end{array}$} & \multicolumn{9}{|c|}{ Preincubated base } \\
\hline & & & \multicolumn{3}{|c|}{ None } & \multicolumn{3}{|c|}{ MME } & \multicolumn{3}{|c|}{ DME } \\
\hline & & & \multicolumn{9}{|c|}{ Distribution of radioactivity among phospholipid bases } \\
\hline & & & MME & DME & Choline & MME & DME & Choline & MME & DME & Choline \\
\hline & & & \multicolumn{3}{|c|}{ per cent } & \multicolumn{3}{|c|}{ per cent } & \multicolumn{3}{|c|}{ per cent } \\
\hline \multirow{2}{*}{ Choline $(+)$} & Male & 2 & 4.0 & 7.7 & 88.3 & 3.6 & 24.1 & 72.3 & 1.7 & 6.2 & 92.1 \\
\hline & Female & 3 & 3.8 & 10.2 & 86.0 & 2.1 & 21.8 & 76.1 & 2.3 & 6.3 & 91.4 \\
\hline \multirow{2}{*}{ Choline $(-)$} & Male & 3 & 1.8 & 4.6 & 93.6 & 0.6 & 23.8 & 75.6 & 0.9 & 5.6 & 93.5 \\
\hline & Female & e 2 & 2.3 & 7.5 & 90.2 & 0.6 & 18.8 & 80.6 & 0.7 & 5.0 & 94.3 \\
\hline
\end{tabular}




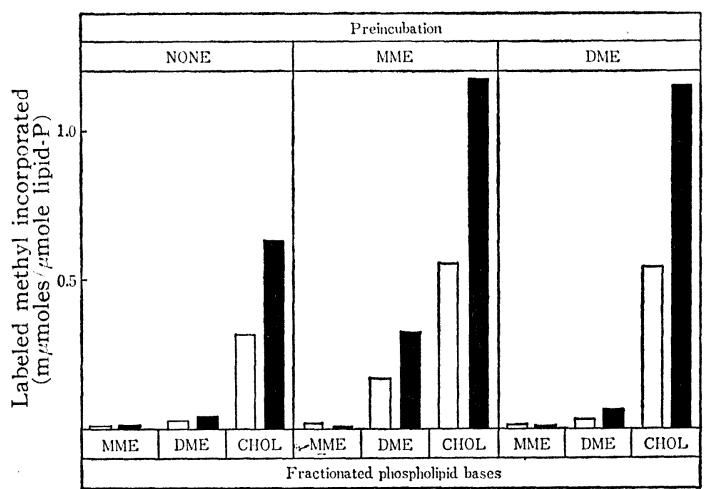

FIG. 7 Incorporation of labeled methyl group of L-methionine- $\mathrm{C}^{3} \mathrm{H}_{3}$ into phosphatidyl-MME, -DME and lecithin of liver slices

Amount of methyl group incorporated into each of the three phospholipid bases, MME, DME and choline (CHOL), was calculated from total incorporation (Table 8 ) and percent distribution of radioactivity (Table 9). White columns, choline-supplemented group; black columns, choline-deficient group.

MME-preincubated slices that radioactivity was detected to an appreciable extent in the intermediates. In all slices most of the labeled methyl was found in the cholinefraction, i.e. the methylation proceeded to the last step.

\section{Discussion}

There have been several reports concerning phospholipid synthesis in the cholinedeficient animals (24-29). DiLuzio and Zilversmit reported impairment of the synthesis of choline-containing phospholipids in liver slices of choline-deficient dog and reactivation of it by choline added in vitro over the value of the controls (24). They also reported a higher incorporation of ${ }^{32} \mathrm{P}$, added in vivo, into liver phospholipids of the choline-deficient dogs than that of the controls (25). Blumenstein recently reported that in the choline-deficient rat the direct incorporation of injected choline into liver lecithin was unchanged, whereas the incorporation of the methyl group of methionine into lecithin, and of ethanolamine into phosphatidyl-ethanolamine was decreased (26).

Our present results indicated the increased incorporation of ${ }^{32} \mathrm{PO}_{4}$ (Table 3, Fig. 4) and choline $-{ }^{14} \mathrm{CH}_{3}$ (Table 4, Fig. 4) into the lecithin fraction of liver slices obtained from the cholin-deficient guinea pigs, compared with the controls, whereas the incorporation of ${ }^{32} \mathrm{PO}_{4}$ and ethanolamine $-{ }^{14} \mathrm{C}$ into phosphatidylethanolamine remained unchanged (Table 6, Fig. 4). The mechanism by which these results were obtained is, however, obscure. There seem to be two possible explanations. One it the actual increment of enzyme activities concerned in the lecithin synthesis from these precursors in a choline-deficient state. Another explanation is that the apparent higher incorporation in the cholinedeficient group is due to the dilution of the radioactive precursors with the endogenous substances at any one of the intermediate steps. The concentration of choline ${ }^{14} \mathrm{CH}_{3}$ in the reaction medium employed was relatively low. Therefore, its incorporation might be affected by dilution with nonlabeled free choline or its derivatives in the cell, which were reported to be low in the choline-deficient guinea pig livers (3). The possibility that the decreased concentration of ATP in the liver, observed in the choline-deficient rat (30), affected the incorporation of ${ }^{32} \mathrm{PO}_{4}$ by dilution at the step of ATP was denied, since ${ }^{32} \mathrm{PO}_{4}$ was incorporated into phosphatidylethanolamine of the liver slices in the control roup as efficiently as in the choline-deficient group. Dilution must have occurred, if any, at the level of phosphorylcholine or CDP. choline.

On the other hand, several authors have described the increased activity of lecithin synthesis through methylation pathway in choline-deficiency (27-29): Strength et al. reported that injected methionine $-{ }^{14} \mathrm{CH}_{3}$ was incorporated into lipid choline of the liver in choline-deficient rats with thrice as high specific activity that in the controls (27); Wells reported that in choline-deficient rats the rate of choline synthesis by methylation was twice that of the controls, while decay time and the amount of liver choline were the same for the controls (28); Corredor et al. showed much faster incorporation of methyl 
group of $S$-adenosylmethionine into lecithin of liver homogenate in the choline-deficient rats than in the controls (29). It has been reported that lecithin formation by methylation of phosphatidylethanolamine was very low, or almost defective, in guinea pig liver in comparison with rat (7).

Our data clearly show that this pathway does exist in guinea pig liver, and that this is elevated nearly twice in a choline-deficient state. In rats the increase of this pathway may be interpreted as an adaptive metabolic change to synthesize lipid choline by this alternative route in choline deficiency, since the liver of this species has high activity to convert phosphatidylethanolamine to lecithin $(7,17,31)$. In guinea pigs, however, the significance of the elevation of the methylation pathway is somewhat obscure, since this species does not have the ability to synthesize phosphatide choline enough to supplement the daily requirement for normal growth (1, 6). Methionine activating enzyme activity seems not to be responsible for the higher incorporation of labeled methyl group of methionine into phospholipids in the cholinedeficient group than in the control. It is possible that the increased activity of phosphatidylmethyltransferase(s) thus suggested is, as postulated for rats, an adaptive metabolic change to supplement choline, though insufficient. Moreover, considering the death of two-thirds of the deficient animals, there seems to have occurred a sort of selection during the four weeks through choline-deficiency, so that only the guinea pigs, whose methylating ability was enhanced to a relatively high degree, might survive longer.

The results shown in Tables 8 and 9 and Fig. 4 suggest that phosphatidyl-MME and phosphatidyl-DME were methylated much more effectively in guinea pig liver than the endogenous phosphatidylethanolamine, and confirms the nutritional studies which reported the effectiveness of MME + methionine, MME + betaine or DME alone as substitutes for choline in the growth of young guinea pigs but the ineffectiveness of ethanolamine $(1,6)$.
The considerable radioactivity found in the DME-fraction of the MME-preincubated slices (Table 9, Fig. 6) are considered to be derived through methylation of phosphatidylMME, a better methyl acceptor, which might have accumulated in the slices during the preincubation period. Then, it seems curious that the radioisotope was scarcely found in the MME-fraction of these slices, since freshly synthesized labeled phosphatidyl-MME was to be trapped by the accumulated nonlabeled phosphatidyl-MME, provided that phosphatidylethanolamine was the starting methyl acceptor. Preincubation of the slices with MME or DME augmented the methyl incorporation in both the choline-deficient and the control group almost in the same proportion (Table 8), and did not alter the distribution of radioactive methyl group among phospholipid bases (Table 9). These facts may suggest that the same enzyme (or an enzyme complex) is operative for each of the three methylation steps. In that case the methylation starting with phosphatidylethanolamine must proceed to phosphatidyl-DME without releasing the intermediate, phosphatidyl-MME. Another possibility is that the methylation of the endogenous phosphatidylethanolamine does not occur in the presence of phosphatidyl-MME or -DME, more effective methyl acceptors. Much more informations are necessary on the mechanism of action of phosphatidylmethyltransferase enzyme system. Rehbinder and Greenberg (32) reported in this regard a partially purified preparation which methylated synthetic phosphatidyl-MME and -DME but did not methylate phosphatidylethanolamine.

\section{REFERENCES}

1. Reid, M.E., J. Nutrition, 56, 215 (1955).

2. Suzuki, S., Vitamins, 34, 192 (1966).

3. Tani, H., Suzuki, S., Kobayashi, M., and Kotake, Y., J. Nutrition, 92, 317 (1967).

4. Handler, P., Proc. Soc. Exp. Biol. Med., 70, 70 (1949).

5. Casselman, W.G.B., and Williams, G.R., Nature, 173, 210 (1954).

6. Young, R. J., and Lucas, C. C., Can. J. Biochem. Physiol., 35, 1 (1957). 
7. Pilgeram, L. O., and Greenberg, D. M., Science, 120, 760 (1954).

8. Folch, J., Lees, M., and Sloan-Stanley, G. H., J. Biol. Chem., 226, 497 (1957).

9. Bremer, J., and Greenberg, D. M., Biochim. Biophys. Acta, 35, 287 (1959).

10. Gornall, A. G., Bardawill, C.S., and David, M. M., J. Biol. Chem., 177, 751 (1949), Layne, E., Methods in Enzymology, edited by S.P. Colowick and N. O. Kaplan, Academic Press Inc., New York, Vol. III, p. 451 (1957).

11. Cantoni, G. L., and Durell, J., J. Biol. Chem., 225, 1033 (1957).

12. Allen, R. J. L., Biochem. J., 34, 858 (1940).

13. Spitzer, H. L., Morrison, K., and Norman, J. R., Biochim. Biophys. Acta, 152, 552 (1968).

14. Morgan, T.E., Finley, T. N., and Fialkow, H., Biochim. Biophys. Acta, 106, 403 (1965).

15. Dils, R. R., and Hübscher, G., Biochim. Biophys. Acta, 46, 505 (1961).

16. Kennedy, E. P., and Weiss, S. B., J. Biol. Chem., 222, 193 (1956).

17. Bremer, J., Figard, P. H., and Greenberg, D. M., Biochim. Biophys. Acta, 43, 477 (1960).

18. Bremer, J., and Greenberg, D. M., Biochim.
Biophys. Acta, 46, 205 (1961).

19. Gibson, K. D., Wilson, J. D., and Udenfriend, S., J. Biol. Chem., 236, 673 (1961).

20. Artom, C., and Lofland, H. B. (Jr.), Biochem. Biophys. Res. Commun., 3, 244 (1960).

21. Artom, C., Federation Proc., 19, 233 (1960).

22. Artom, C., Federation Proc., 21, 297 (1962).

23. Artom, C., Biochem. Biophys. Res. Commun., 15, 201 (1964).

24. DiLuzio, N. R., and Zilversmit, D. B., J. Biol. Chem., 205, 867 (1953).

25. DiLuzio, N. R., and Zilversmit, D. B., Amer. J. Physiol., 196, 887 (1959).

26. Blumenstein, J., Can. J. Physiol. Pharmacol., 46, 487 (1968).

27. Strength, D. R., Bell, O. E., and Davis, E. Y., Federation Proc., 22, 652 (1963).

28. Wells, I. C., Federation Proc., 22, 652 (1963).

29. Corredor, C., Mansbach, C., and Bressler, R., Biochim. Biophys. Acta, 144, 366 (1967).

30. Dianzani, M. U., Biochem. J., 65, 116 (1957).

31. Bjфrnstad, P., and Bremer, J., J. Lipid Res., 7, 38 (1966).

32. Rehbinder, D., and Greenberg, D. M., Arch. Biochem. Biophys., 109, 110 (1965). 